\title{
Genetic population structure of marine viral haemorrhagic septicaemia virus (VHSV) ${ }^{\star}$
}

\author{
M. Snow ${ }^{1, *}$, N. Bain ${ }^{1}$, J. Black ${ }^{1}$, V. Taupin ${ }^{1}$, C. O. Cunningham ${ }^{1}$, J. A. King ${ }^{1}$, \\ H. F. Skall ${ }^{2}$, R. S. Raynard ${ }^{1}$ \\ ${ }^{1}$ Fisheries Research Services (FRS) Marine Laboratory, PO Box 101, 375 Victoria Road, Aberdeen, AB11 9DB, Scotland, UK \\ ${ }^{2}$ Department of Poultry, Fish and Fur Animals, Danish Institute for Food and Veterinary Research, Hangøvej 2, \\ 8200 Århus N, Denmark
}

\begin{abstract}
The nucleotide sequences of a specific region of the nucleoprotein gene were compared in order to investigate the genetic population structure of marine viral haemorrhagic septicaemia virus (VHSV). Analysis of the sequence from 128 isolates of diverse geographic and host origin renders this the most comprehensive molecular epidemiological study of marine VHSV conducted to date. Phylogenetic analysis of nucleoprotein gene sequences confirmed the existence of the 4 major genotypes previously identified based on N- and subsequent G-gene based analyses. The range of Genotype I included subgroups of isolates associated with rainbow trout aquaculture (Genotype Ia) and those from the Baltic marine environment (Genotype Ib) to emphasise the relatively close genetic relationship between these isolates. The existence of an additional genotype circulating within the Baltic Sea (Genotype II) was also confirmed. Genotype III included marine isolates from around the British Isles in addition to those associated with turbot mariculture, highlighting a continued risk to the development of this industry. Genotype IV consisted of isolates from the marine environment in North America. Taken together, these findings suggest a marine origin of VHSV in rainbow trout aquaculture. The implications of these findings with respect to the future control of VHSV are discussed. The capacity for molecular phylogenetic analysis to resolve complex epidemiological problems is also demonstrated and its likely future importance to disease management issues highlighted.
\end{abstract}

KEY WORDS: Viral Haemorrhagic Septicaemia Virus · VHSV · VHS · Nucleoprotein · Phylogenetics

\section{INTRODUCTION}

Viral haemorrhagic septicaemia (VHS) is a disease which, until the late 1980s, was widely thought to be confined to farmed rainbow trout Oncorhynchus mykiss in continental Europe. Multiple occurrences of disease have since, however, been associated with European marine aquaculture (Schlotfeldt et al. 1991,

$\star$ Nucleotide sequences reported in this paper have been submitted to the GenBank database and designated the accession numbers detailed in Table 1. Sequences may also be retrieved in FASTA format from www.fishpathogens.net (Snow et al. 2004). Alignment available on request
Ross et al. 1994) and a widespread marine distribution of the causative agent, viral haemorrhagic septicaemia virus (VHSV), is now acknowledged. Indeed, over 150 virus isolations have now been made from a wide range of marine host species in north European waters (Smail 1995, Dixon et al. 1997, Mortensen et al. 1999, Smail 2000, King et al. 2001a, Brudeseth \& Evensen 2002). These isolates have been shown to differ from their freshwater counterparts since all of those tested to date have exhibited a generally low pathogenicity to rainbow trout (Dixon et al. 1997, Skall et al. 2004). The existence of a marine reservoir of VHSV has, however, been shown to pose a direct risk to turbot culture in Europe (Stone et al. 1997, Snow \& Smail 1999, Snow et 
al. 1999), and may represent an emerging risk for other important mariculture and wild fish species.

The etiological agent of VHS is a member of the genus Novirhabdoviridae (van Regenmortel et al. 2000) and as such, has a single-stranded non-segmented negative sense RNA genome consisting of 6 genes in the order 3' N-P-M-G-NV-L 5'. Variability within these genes has been used to investigate the spatio-temporal genetic relationships between a range of freshwater and marine viral isolates. Previous studies based on both nucleoprotein $(\mathrm{N})$ and glycoprotein (G) gene sequences have identified the existence of 4 genotypes of virus, circulating within discrete geographic areas.

Genotype I includes a wide range of viruses originating from freshwater rainbow trout farms in continental Europe (Benmansour et al. 1997, Stone et al. 1997, Snow et al. 1999, Nishizawa et al. 2002, Thiery et al. 2002, Einer-Jensen et al. 2004). To date, a total of 28 isolates originating from marine species in the Baltic Sea/Skagerrak/Kattegat and a single isolate originating from the English channel (Atlantic herring Clupea harengus isolate 96-43; Dixon et al. 1997) have also shown to be members of this genotype (Snow et al. 1999, Einer-Jensen et al. 2004). Interestingly, a single isolate from farmed Japanese flounder Paralichthys olivaceus (isolate JP-KRRV9601; Nishizawa et al. 2002) was also classified within Genotype I, although this isolate is believed to have been accidentally imported (Nishizawa et al. 2002). The close genetic relationship between marine and freshwater VHSV isolates in Genotype I, coupled with historical evidence, has led to the hypothesis that VHSV in rainbow trout farms may have had a marine origin (reviewed by Dixon 1999).

A second genotype of VHSV was first identified based on comparative study of the N-gene (Snow et al. 1999). This genetic grouping comprised 5 marine isolates recovered from within the Baltic Sea. The existence of this grouping was recently confirmed by analyses of G-gene nucleotide variation (Einer-Jensen et al. 2004).

A third genetic group has been identified, which includes isolates originating from outbreaks of VHS in turbot farms in the British Isles (UK-860/94, Ross et al. 1994; IR-F13.02.97, J. McArdle unpubl. data) along with 12 isolates from a variety of marine species caught in Scottish waters (Snow et al. 1999, Einer-Jensen et al. 2004). Such findings highlighted the potential risk to turbot mariculture from an endemic marine reservoir of VHSV. Recently, an additional isolate originating from an eel captured in the Atlantic River Loire estuary (FR-L59X), France, has also been shown to be a member of this genetic group (Thiery et al. 2002, EinerJensen et al. 2004).
The final genetic group of VHSV isolates identified to date comprises a range of isolates recovered from wild marine fish in the Pacific Northwest (Benmansour et al. 1997, Stone et al. 1997, Snow et al. 1999, Nishizawa et al. 2002 ). Isolates from Japanese flounder have also, based on G-gene sequences, recently been shown to be members of this same genotype (Nishizawa et al. 2002).

Molecular epidemiology has thus far proved to be a powerful tool in understanding the risk presented by the existence of a marine reservoir of VHSV to aquaculture operations. Given the dramatic increase in the number of isolates recovered from the marine environment in recent years, this study sought to further define the genetic population structure of marine VHSV and thus, contribute to the future management and understanding of this significant viral pathogen.

\section{MATERIALS AND METHODS}

Cell lines and viruses. The VHSV isolates included in this study are detailed in Table 1. The epithelioma papulosum cyprini (EPC) (Fijan et al. 1983) and bluegill fry trunk (BF-2) cell lines (Wolf \& Quimby 1966) were used to propagate virus. Cells were grown at $23^{\circ} \mathrm{C}$ in Glasgow modified minimal essential medium (G-MEM, Gibco BRL, Life Technologies) or L-15 media (BF-2) supplemented with $10 \%$ foetal bovine serum (Sigma-Aldrich).

RNA extraction. Flasks $\left(25 \mathrm{~cm}^{2}\right)$, seeded with the appropriate cell line, were infected with VHSV isolates at a multiplicity of infection (MOI) of approximately 1. At $24 \mathrm{~h}$ post-seeding, medium was removed from cell cultures and replaced with $150 \mu$ virus stock diluted to $1 \mathrm{ml}$ with fresh medium. The virus was left for $2 \mathrm{~h}$ to adsorb at $15^{\circ} \mathrm{C}$ prior to the addition of a further $4 \mathrm{ml}$ of medium. Mock-infected control cell cultures were also utilised. Cells were incubated at $15^{\circ} \mathrm{C}$ until indication of an early cytopathic effect (CPE)(24 to $48 \mathrm{~h})$. At this point, the overlying medium was carefully removed, $2.4 \mathrm{ml}$ TRIzOL (Gibco BRL, Life Tehnologies) were added and the adherent cells were detached using a cell scraper. The TRIzol from each flask was then passed repeatedly through a pipette prior to transfer of $800 \mu \mathrm{l}$ to each of three $1.5 \mathrm{ml}$ tubes. Total RNA was then extracted from each tube according to the manufacturer's instructions. Total RNA from each tube was resuspended in $5 \mu \mathrm{l}$ of diethyl pyrocarbonate (DEPC)treated water and the purified RNA was pooled for each isolate or control.

Reverse transcription and polymerase chain reaction (RT-PCR). Three separate reverse transcription (RT) reactions were performed for each isolate, each using $5 \mu$ l of RNA purified as detailed above. In each 
Table 1. List of 128 viral haemorrhagic septicaemic virus (VHSV) isolates included in this study. Isolates in bold face represent unique representative sequences. Isolates following each representative sequence were found to have exactly the same nucleotide sequence. ${ }^{1}$ Origin of the isolate was from farmed freshwater fish. ${ }^{2}$ Isolates from farmed seawater fish. All other sequences originated from wild-caught marine fish species. Where possible citations refer to details of the original isolation. For reasons of consistency, all remaining isolates are referred to by names first given in the cited references. ${ }^{*}$ Accession numbers of sequences not sequenced by the authors. Isolates are listed according to the genotypes identified as a result of this study. Values in parentheses

(n) refer to the number of isolates classified within each genotype. DFVF: Danish Institute for Food and Veterinary Research

\begin{tabular}{|c|c|c|c|c|c|}
\hline Virus isolate & $\begin{array}{l}\text { Year of } \\
\text { isolation }\end{array}$ & $\begin{array}{c}\text { Geographic } \\
\text { origin }\end{array}$ & $\begin{array}{l}\text { Genotype } \\
\text { Host species }\end{array}$ & Source & $\begin{array}{c}\text { Accession } \\
\text { no. }\end{array}$ \\
\hline & & & Genotype I $(n=88)$ & & \\
\hline DK-F1 ${ }^{1}$ & 1962 & Denmark & Oncorhynchus mykiss & Jensen (1965) & AY356633 \\
\hline DK-Hededam ${ }^{1}$ & 1972 & Denmark & Oncorhynchus mykiss & Vestergård Jørgensen (1974) & Z93412* \\
\hline & & & Genotype Ia $(n=21)$ & & \\
\hline FR-07/71 1 & 1971 & France & Oncorhynchus mykiss & Le Berre et al. (1977) & AJ233396* \\
\hline DK-3345 ${ }^{1}$ & 1985 & Denmark & Oncorhynchus mykiss & DFVF (unpubl.) & AY356639 \\
\hline DK-5133 ${ }^{1}$ & 1988 & Denmark & Oncorhynchus mykiss & DFVF (unpubl.) & AY356642 \\
\hline FR-1458 ${ }^{1}$ & 1990 & France & Oncorhynchus mykiss & Thiery et al. (2002) & AF143863* \\
\hline DE-7321 (5927) ${ }^{2}$ & 1991 & Germany & Scophthalmus maximus & Schlotfeldt et al. (1991) & AJ130922 \\
\hline DK-6143 ${ }^{1}$ & 1991 & Denmark & Oncorhynchus mykiss & DFVF (unpubl.) & AY356645 \\
\hline DK-9895174 ${ }^{1}$ & 1998 & Denmark & Oncorhynchus mykiss & DFVF (unpubl.) & AY356638 \\
\hline DK-3592B ${ }^{1}$ & 1986 & Denmark & Oncorhynchus mykiss & Lorenzen et al. (1993) & $\mathrm{AF} 012093^{*}$ \\
\hline DK-5243 ${ }^{1}$ & 1988 & Denmark & Oncorhynchus mykiss & DFVF (unpubl.) & AY356643 \\
\hline DK- $6047^{2}$ & 1991 & Denmark & Oncorhynchus mykiss & DFVF (unpubl.) & AY356644 \\
\hline DK-3955 ${ }^{1}$ & 1987 & Denmark & Oncorhynchus mykiss & DFVF (unpubl.) & AY356640 \\
\hline DK- $3956^{1}$ & 1987 & Denmark & Oncorhynchus mykiss & DFVF (unpubl.) & AY356641 \\
\hline DK-7217 ${ }^{1}$ & 1994 & Denmark & Oncorhynchus mykiss & DFVF (unpubl.) & AY356646 \\
\hline DK-7300 1 & 1994 & Denmark & Oncorhynchus mykiss & DFVF (unpubl.) & AY356647 \\
\hline DK-7309 ${ }^{1}$ & 1994 & Denmark & Oncorhynchus mykiss & DFVF (unpubl.) & AY356648 \\
\hline DK- $7655^{1}$ & 1994 & Denmark & Oncorhynchus mykiss & DFVF (unpubl.) & AY356649 \\
\hline DK- $7483^{1}$ & 1995 & Denmark & Oncorhynchus mykiss & DFVF (unpubl.) & AY356650 \\
\hline DK-9795159 1 & 1997 & Denmark & Oncorhynchus mykiss & DFVF (unpubl.) & AY356636 \\
\hline DK-9795265 & 1997 & Denmark & Oncorhynchus mykiss & DFVF (unpubl.) & AY356637 \\
\hline DK-9695152 ${ }^{2}$ & 1996 & Denmark & Oncorhynchus mykiss & DFVF (unpubl.) & AY356634 \\
\hline DK-9695297² & 1996 & Denmark & Oncorhynchus mykiss* & DFVF (unpubl.) & AY356635 \\
\hline & & & Genotype Ib $(n=65)$ & & \\
\hline DK-M.Rhabdo & 1979 & Baltic Sea & Gadus morhua & Jensen et al. (1979) & AY356632 \\
\hline DK-1p3 & 1996 & Baltic Sea & Clupea harenqus & Mortensen et al. (1999) & AY356651 \\
\hline DK-1p8 & 1996 & Baltic Sea & Clupea harengus & Mortensen et al. (1999) & AY356652 \\
\hline DK-1p12 & 1996 & Baltic Sea & Clupea harengus & Mortensen et al. (1999) & AY356653 \\
\hline DK-1p50 & 1996 & Baltic Sea & Sprattus sprattus & Mortensen et al. (1999) & AJ130920 \\
\hline DK-1p64 & 1996 & Baltic Sea & Clupea harengus & Mortensen et al. (1999) & AY356654 \\
\hline DK-1p85 & 1996 & Baltic Sea & Clupea harengus & Mortensen et al. (1999) & AY356655 \\
\hline DK-1p86 & 1996 & Baltic Sea & Sprattus sprattus & Mortensen et al. (1999) & AY356656 \\
\hline DK-1p93 & 1996 & Baltic Sea & Gadus morhua & Mortensen et al. (1999) & AY356657 \\
\hline DK-1p109 & 1996 & Baltic Sea & Gadus morhua & Mortensen et al. (1999) & AY356658 \\
\hline DK-1p110 & 1996 & Baltic Sea & Clupea harengus & Mortensen et al. (1999) & AY356659 \\
\hline DK-1p111 & 1996 & Baltic Sea & Sprattus sprattus & Mortensen et al. (1999) & AY356660 \\
\hline DK-1p116 & 1996 & Baltic Sea & Gadus morhua & Mortensen et al. (1999) & AY356661 \\
\hline DK-1p120 & 1996 & Baltic Sea & Clupea harengus & Mortensen et al. (1999) & AY356662 \\
\hline DK-1p121 & 1996 & Baltic Sea & Sprattus sprattus & Mortensen et al. (1999) & AY356663 \\
\hline DK-1p124 & 1996 & Baltic Sea & Sprattus sprattus & Mortensen et al. (1999) & AY356664 \\
\hline DK-1p125 & 1996 & Baltic Sea & Clupea harengus & Mortensen et al. (1999) & AY356665 \\
\hline DK-1p128 & 1996 & Baltic Sea & Sprattus sprattus & Mortensen et al. (1999) & AY356666 \\
\hline DK-1e62 & 1996 & Baltic Sea & Gadus morhua & Mortensen et al. (1999) & AY356668 \\
\hline UK-96-43 & 1997 & English Channel & Clupea harengus & Dixon et al. (1997) & AF143862* \\
\hline DK-5p26 & 1998 & Kattegat & Limanda limanda & Skall et al. (unpubl.) & AY356673 \\
\hline DK-5p48 & 1998 & Kattegat & Limanda limanda & Skall et al. (unpubl.) & AY356675 \\
\hline DK-5e59 & 1998 & Kattegat & Limanda limanda & Skall et al. (unpubl.) & AY356669 \\
\hline DK-5e62 & 1998 & Kattegat & Limanda limanda & Skall et al. (unpubl.) & AY356670 \\
\hline DK-5e63 & 1998 & Kattegat & Limanda limanda & Skall et al. (unpubl.) & AY356671 \\
\hline DK-5p11 & 1998 & Skagerrak & Pleuronectes platessa & Skall et al. (unpubl.) & AY356672 \\
\hline DK-5p251 & 1998 & Kattegat & Clupea harengus & Skall et al. (unpubl.) & AY356678 \\
\hline DK-5p253 & 1998 & Kattegat & Clupea harengus & Skall et al. (unpubl.) & AY356679 \\
\hline
\end{tabular}


Table 1. (continued)

\begin{tabular}{|c|c|c|c|c|c|}
\hline Virus isolate & $\begin{array}{c}\text { Year of } \\
\text { isolation }\end{array}$ & $\begin{array}{l}\text { Geographic } \\
\text { origin }\end{array}$ & $\begin{array}{l}\text { Genotype } \\
\text { Host species }\end{array}$ & Source & $\begin{array}{c}\text { Accession } \\
\text { no. }\end{array}$ \\
\hline \multicolumn{6}{|c|}{ Genotype Ib $(\mathrm{n}=65)$ (continued) } \\
\hline DK-5p263 & 1998 & Kattegat & Clupea harengus & Skall et al. (unpubl.) & AY356680 \\
\hline DK-5p276 & 1998 & Kattegat & Pleuronectes platessa & Skall et al. (unpubl.) & AY356681 \\
\hline DK-5p393 & 1998 & Baltic Sea & Clupea harengus & Skall et al. (unpubl.) & AY356682 \\
\hline DK-5p405 & 1998 & Baltic Sea & Limanda limanda & Skall et al. (unpubl.) & AY356683 \\
\hline DK-5p439 & 1998 & Baltic Sea & Clupea harengus & Skall et al. (unpubl.) & AY356684 \\
\hline DK-5p441 & 1998 & Baltic Sea & Clupea harengus & Skall et al. (unpubl.) & AY356685 \\
\hline DK-5p442 & 1998 & Baltic Sea & Clupea harengus & Skall et al. (unpubl.) & AY356686 \\
\hline DK-5p448 & 1998 & Baltic Sea & Clupea harengus & Skall et al. (unpubl.) & AY356688 \\
\hline DK-5p449 & 1998 & Baltic Sea & Clupea harengus & Skall et al. (unpubl.) & AY356689 \\
\hline DK-5e 454 & 1998 & Baltic Sea & Platichthys flesus & Skall et al. (unpubl.) & AY356687 \\
\hline DK-5p457 & 1998 & Baltic Sea & Sprattus sprattus & Skall et al. (unpubl.) & AY356692 \\
\hline DK-5p508 & 1998 & Baltic Sea & Clupea harengus & Skall et al. (unpubl.) & AY356693 \\
\hline DK-5p513 & 1998 & Baltic Sea & Sprattus sprattus & Skall et al. (unpubl.) & AY356694 \\
\hline DK-5p514 & 1998 & Baltic Sea & Sprattus sprattus & Skall et al. (unpubl.) & AY356695 \\
\hline DK-5p524 & 1998 & Baltic Sea & Sprattus sprattus & Skall et al. (unpubl.) & AY356696 \\
\hline DK-5p527 & 1998 & Baltic Sea & Sprattus sprattus & Skall et al. (unpubl.) & AY356697 \\
\hline DK-5p547 & 1998 & Baltic Sea & Clupea harengus & Skall et al. (unpubl.) & AY356698 \\
\hline DK-5p663 & 1998 & Baltic Sea & Clupea harengus & Skall et al. (unpubl.) & AY356699 \\
\hline DK-5p669 & 1998 & Baltic Sea & Sprattus sprattus & Skall et al. (unpubl.) & AY356703 \\
\hline DK-5p670 & 1998 & Baltic Sea & Sprattus sprattus & Skall et al. (unpubl.) & AY356704 \\
\hline DK-5p671 & 1998 & Baltic Sea & Sprattus sprattus & Skall et al. (unpubl.) & AY356705 \\
\hline DK-5p673 & 1998 & Baltic Sea & Sprattus sprattus & Skall et al. (unpubl.) & AY356706 \\
\hline DK-5p674 & 1998 & Baltic Sea & Sprattus sprattus & Skall et al. (unpubl.) & AY356707 \\
\hline DK-5p675 & 1998 & Baltic Sea & Sprattus sprattus & Skall et al. (unpubl.) & AY356708 \\
\hline DK-5p676 & 1998 & Baltic Sea & Sprattus sprattus & Skall et al. (unpubl.) & AY356709 \\
\hline DK-5p677 & 1998 & Baltic Sea & Sprattus sprattus & Skall et al. (unpubl.) & AY356710 \\
\hline DK-5p678 & 1998 & Baltic Sea & Sprattus sprattus & Skall et al. (unpubl.) & AY356712 \\
\hline DK-5p679 & 1998 & Baltic Sea & Sprattus sprattus & Skall et al. (unpubl.) & AY356711 \\
\hline DK-5p680 & 1998 & Baltic Sea & Sprattus sprattus & Skall et al. (unpubl.) & AY356713 \\
\hline DK-7p37 & 2001 & Baltic sea & Pomatoschistus minutus & Skall et al. (unpubl.) & AY356715 \\
\hline DK-7e97 & 2001 & Baltic sea & Clupea harengus & Skall et al. (unpubl.) & AY356714 \\
\hline DK-7e538 & 2001 & Baltic Sea & Clupea harengus & Skall et al. (unpubl.) & AY356716 \\
\hline DK-7e544 & 2001 & Baltic Sea & Clupea harengus & Skall et al. (unpubl.) & AY356717 \\
\hline DK-1p40 & 1996 & Baltic Sea & Rhinonemus cimbrius & Mortensen et al. (1999) & AJ130919 \\
\hline DK-5p31 & 1998 & Kattegat & Clupea harengus & Skall et al. (unpubl.) & AY356674 \\
\hline DK-5p201 & 1998 & Kattegat & Clupea harengus & Skall et al. (unpubl.) & AY356676 \\
\hline \multirow[t]{2}{*}{ DK-5p213 } & 1998 & Kattegat & Clupea harengus & Skall et al. (unpubl.) & AY356677 \\
\hline & & & Genotype II (n = 7) & & \\
\hline DK-1p49 & 1996 & Baltic Sea & Clupea harengus & Mortensen et al. (1999) & AY356743 \\
\hline DK-1p53 & 1996 & Baltic Sea & Clupea harengus & Mortensen et al. (1999) & AJ130921 \\
\hline DK-1p52 & 1996 & Baltic Sea & Sprattus sprattus & Mortensen et al. (1999) & AY356744 \\
\hline DK-1p54 & 1996 & Baltic Sea & Gadus morhua & Mortensen et al. (1999) & AY356745 \\
\hline DK-1p55 & 1996 & Baltic Sea & Sprattus sprattus & Mortensen et al. (1999) & AY356746 \\
\hline DK-5p551 & 1998 & Baltic Sea & Clupea harengus & Skall et al. (unpubl.) & AY356690 \\
\hline \multirow[t]{2}{*}{ DK-5p557 } & 1998 & Baltic Sea & Clupea harengus & Skall et al. (unpubl.) & AY356691 \\
\hline & & & Genotype III $(n=30)$ & & \\
\hline UK-H17/1/95 & 1995 & North Sea & Melanogrammus aeglefinus & Smail (2000) & AY356720 \\
\hline UK-H17/2/95 & 1995 & North Sea & Melanogrammus aeglefinus & Smail (2000) & AJ130924 \\
\hline UK-MLA98/6PT10 & 01998 & North Sea & Trisopterus esmarkii & King et al. (2001) & AY356723 \\
\hline UK-MLA98/6PT13 & 31998 & North Sea & Trisopterus esmarkii & King et al. (2001) & AY356721 \\
\hline UK-MLA98/6PT16 & 61998 & North Sea & Trisopterus esmarkii & King et al. (2001) & AY356722 \\
\hline UK-MLA98/4PT6 & 1998 & North Atlantic & Trisopterus esmarkii & King et al. (2001) & AY356741 \\
\hline UK-H17/5/93 & 1993 & North Sea & Gadus morhua & Smail (2000) & AY356727 \\
\hline UK-H19/1/93 & 1993 & North Sea & Gadus morhua & Smail (2000) & AY356728 \\
\hline UK-H16/7/95 & 1995 & North Sea & Gadus morhua & Smail (2000) & AJ130923 \\
\hline DK-4p168 & 1997 & Skagerrak & Clupea harengus & Mortensen et al. (1999) & AY356724 \\
\hline UK-MLA98/6PT17 & 71998 & North Sea & Trisopterus esmarkii & King et al. (2001) & AY356725 \\
\hline UK-MLA98/6PT8 & 1998 & North Sea & Trisopterus esmarkii & King et al. (2001) & AY356726 \\
\hline
\end{tabular}


Table 1. (continued)

\begin{tabular}{|c|c|c|c|c|c|}
\hline Virus isolate & $\begin{array}{l}\text { Year of } \\
\text { solation }\end{array}$ & $\begin{array}{l}\text { Geographic } \\
\text { origin }\end{array}$ & $\begin{array}{l}\text { Genotype } \\
\text { Host species }\end{array}$ & Source & $\begin{array}{c}\text { Accession } \\
\text { no. }\end{array}$ \\
\hline & & & \multicolumn{3}{|c|}{ Genotype III (n = 30) (continued) } \\
\hline UK-MLA98/4PT2 & 1998 & North Atlantic & Trisopterus esmarkii & King et al. (2001) & AY356737 \\
\hline UK-MLA98/4PT3 & 1998 & North Atlantic & Trisopterus esmarkii & King et al. (2001) & AY356738 \\
\hline UK-MLA98/6PT11 & 1998 & North Sea & Trisopterus esmarkii & King et al. (2001) & AY356731 \\
\hline UK-MLA98/6PT15 & 1998 & North Sea & Trisopterus esmarkii & King et al. (2001) & AY356732 \\
\hline UK-MLA98/6PT7 & 1998 & North Sea & Trisopterus esmarkii & King et al. (2001) & AY356733 \\
\hline UK-MLA98/6PT12 & 1998 & North Sea & Trisopterus esmarkii & King et al. (2001) & AY356734 \\
\hline UK-MLA98/4PC1 & 1998 & North Atlantic & Trisopterus minutus & King et al. (2001) & AY356742 \\
\hline DK-2p51 & 1996 & Skagerrak & Trisopterus esmarkii & Mortensen et al. (1999) & AJ130917 \\
\hline DK-4p101 & 1997 & North Sea & Merlangius merlangus & Mortensen et al. (1999) & AJ130918 \\
\hline UK-MLA98/4PT1 & 1998 & North Atlantic & Trisopterus esmarkii & King et al. (2001) & AY356719 \\
\hline UK-860/94 ${ }^{2}$ & 1994 & Gigha & Scophthalmus maximus & Ross et al. (1994 & AJ130915 \\
\hline IR-F $13.02 .97^{2}$ & 1997 & SW Ireland & Scophthalmus maximus & J. McArdle (pers. com.) & AJ130916 \\
\hline UK-MLA98/6WH1 & 1998 & North Sea & Merlangius merlangus & King et al. (2001) & AY356729 \\
\hline UK-MLA98/6PT14 & 1998 & North Sea & Trisopterus esmarkii & King et al. (2001) & AY356730 \\
\hline UK-MLA98/4CO1 & 1998 & North Atlantic & Gadus morhua & King et al. (2001) & AY356735 \\
\hline DK-4p51 & 1997 & North Sea & Argentina sphyraena & Mortensen et al. (1999) & AY356736 \\
\hline UK-MLA98/4PT4 & 1998 & North Atlantic & Trisopterus esmarkii & King et al. (2001) & AY356739 \\
\hline \multirow[t]{2}{*}{ UK-MLA98/4PT5 } & 1998 & North Atlantic & Trisopterus esmarkii & King et al. (2001) & AY356740 \\
\hline & & & Genotype IV (n = 3) & & \\
\hline US-mak-wa88 & 1988 & Washington, USA & Oncorhynchus kisutch & Benmansour et al. (1997) & X59241* \\
\hline US-pws-ak90 & 1990 & Alaska, USA & Gadus macrocephalus & Benmansour et al. (1997) & AJ130926 \\
\hline US-eby-wa93 & 1993 & Washington, USA & Clupea pallasii & Benmansour et al. (1997) & AJ130925 \\
\hline
\end{tabular}

case, cDNA to poly (A)+ RNA was prepared by incubation of total RNA with 56 pmol oligo $(\mathrm{dT})_{15}$ primer and 200 units of Moloney Murine Leukemia virus (MMLV) reverse transcriptase (Invitrogen) in a total reaction volume of $20 \mu \mathrm{l}$ containing $2 \mathrm{mM}$ each dNTP, $0.1 \mathrm{M}$ dithiothreitol (DTT), $5 \times$ first strand buffer $(250 \mathrm{mM}$ Tris- $\mathrm{HCl}_{1} \mathrm{pH} 8.3,375 \mathrm{mM} \mathrm{KCl}, 15 \mathrm{mM} \mathrm{MgCl}_{2}$ invitrogen) and 20 U RNAse Out (Invitrogen).

$\mathrm{PCR}$ reactions were performed in triplicate from separate RT-reactions for each isolate using primers (VN For 5' ATG GAA GGA GGA ATT CGT GAA GCG 3', VN Rev 5' GCG GTG AAG TGC TGC AGT TCC C 3') designed to amplify a region corresponding to bases 1 to 505 of the VHSV N-gene. PCR amplifications were performed in $50 \mu \mathrm{l}$ volumes under mineral oil, using $28 \mathrm{pmol}$ of each primer, in the presence of $1.5 \mathrm{mM} \mathrm{MgCl}_{2}, 10 \mathrm{mM}$ of each dNTP, 2 units of BioTaq polymerase (Bioline) and $1 \times$ PCR buffer $\left(160 \mathrm{mM}\left(\mathrm{NH}_{4}\right)_{2} \mathrm{SO}_{4}, 670 \mathrm{mM}\right.$ Tris- $\mathrm{HCl}$, $\mathrm{pH} 8.8$ at $25^{\circ} \mathrm{C}, 0.1 \%$ Tween-20). Template material consisted of $5 \mu \mathrm{l}$ of cDNA dilution prepared as above. Amplification was conducted on a Techne Genius thermocycler programmed to conduct 35 cycles of denaturing $\left(94^{\circ} \mathrm{C}, 1 \mathrm{~min}\right)$, annealing $\left(55^{\circ} \mathrm{C}, 1 \mathrm{~min}\right)$ and extension $\left(72^{\circ} \mathrm{C}, 1 \mathrm{~min}\right)$ followed by a single final extension step $\left(72^{\circ} \mathrm{C}, 5 \mathrm{~min}\right)$.

Purification and quantification of PCR products. Amplified products were verified by electrophoresis on a $1.5 \%$ agarose gel and purified using the Wizard $^{\circledR}$
PCR Preps DNA purification system according to the manufacturer's instructions (Promega). Purified products were quantified following electrophoresis on a $1.5 \%$ agarose gel alongside standards of known concentration.

Sequence determination of the PCR products. The sequencing primers used were those employed in the amplification of the original PCR products. Triplicate PCR products originating from independent RT reactions were sequenced for each isolate. Sequencing reactions were performed using an Applied Biosystems model 373A automated sequencer with the ABI Prism dye terminator sequencing chemistry according to the manufacturer's instructions.

Sequence analysis. Multiple sequence alignment was performed manually using the MacClade program (Macintosh Version 4, Sinauer Associates). Individual sequences were manually cropped to a pre-defined minimum sequence length (335 nucleotides, nt). Duplicate sequences were identified within MacClade and excluded from the data set. The phylogenetic relationship among VHSV isolates was inferred from single representatives of each sequence obtained, using likelihood, distance and parsimony based approaches within PAUP* (version 4.0b8; Swofford 1993). For the likelihood analysis, the MODELTEST program (Posada \& Crandall 1998) was used to identify the model that best fits the sequence data from 56 different models 
using the Akaike Information Criterion (AIC; Akaike 1974). This model was defined as: rate matrix of $A$ to $C$ $=1, A$ to $\mathrm{G}=0.8460$, A to $\mathrm{T}=1, \mathrm{C}$ to $\mathrm{G}=1, \mathrm{C}$ to $\mathrm{T}=$ 0.1625 and $G$ to $T=1$; base frequencies equal; proportion of invariable sites (I) $=0$; Gamma distribution shape parameter $=1.6368$. The optimum tree generated using the maximum likelihood distances was identified using the heuristic search option implemented in PAUP*. Confidence in the resultant tree topology was assessed using 1000 bootstrap iterations (Felsenstein 1985) using a distance method based on the maximum likelihood distances, followed by a neighbour joining approach. Significant bootstrap values for the major clades were transferred from this to the tree derived from the original data. Maximum parsimony analysis was also performed within PAUP* using a heuristic search with tree-bisection and recombination (TBR) as the branch swapping algorithm.

Mean inter- and intragroup nucleotide and amino acid values were calculated using the MEGA2 package (Kumar et al. 2001), using the number of differences model.

\section{Genotype I $(\mathrm{n}=88)$}

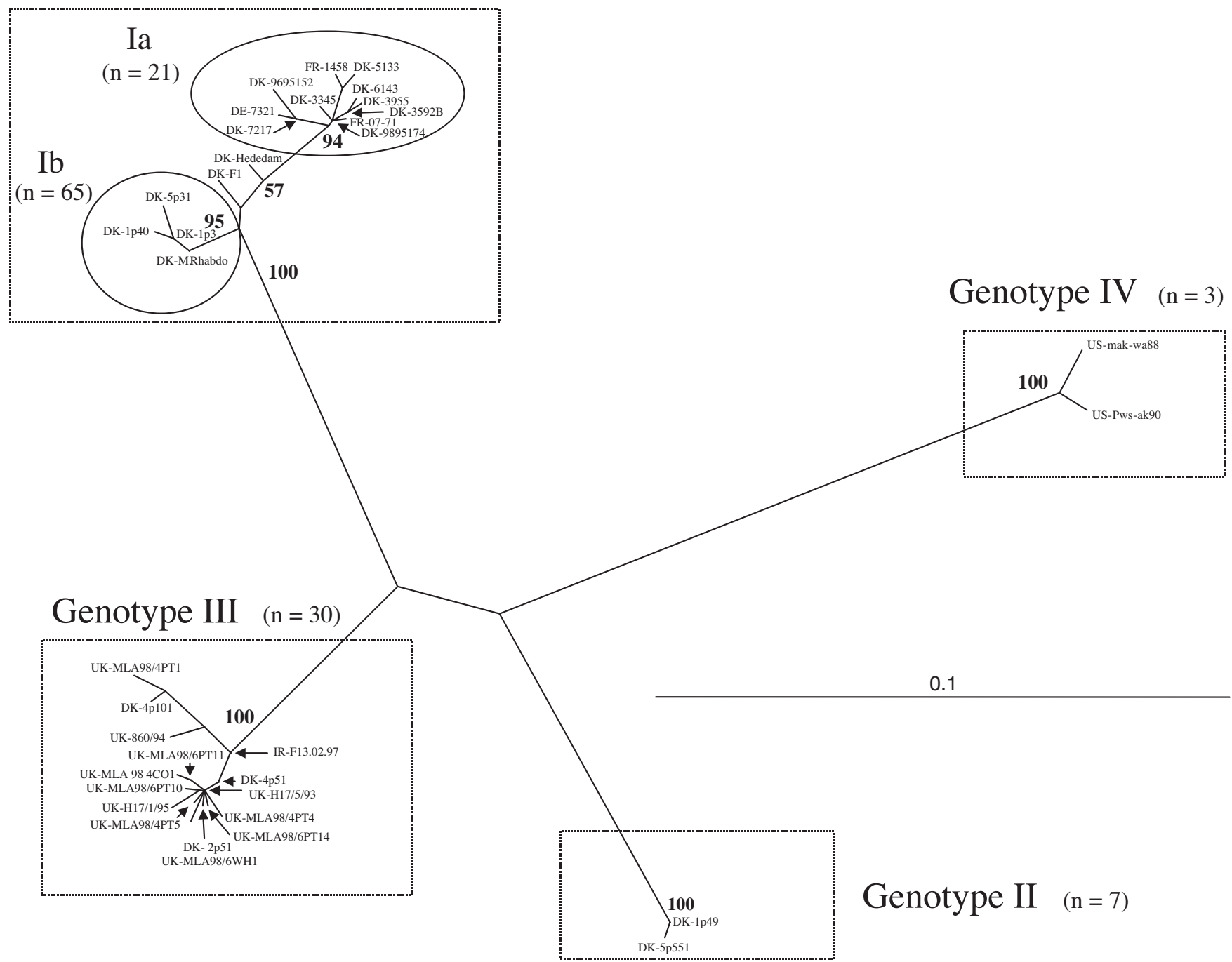

Fig. 1. Phylogenetic classification of marine VHSV isolates, indicating the major genotypes identified. A phylogram was generated from a sequence alignment comprised of representatives of each unique sequence identified from a region of nucleotides 111-445 of the VHSV N-gene open reading frame. MODELTEST was used to identify the model best fitting the data, and the optimum tree generated from maximum likelihood distances using the heuristic search option as implemented in PAUP*. Confidence in the tree topology was assessed using 1000 bootstrap iterations and a distance-based method using the maximum likelihood distances, followed by neighbour joining. Bootstrap values were transferred to the original maximum likelihood tree derived from the actual data. The scale bar indicates the number of substitutions per nucleotide site. Numbers in parentheses (n) indicate the number of isolates assigned to each of the genotypes identified in this study 


\section{RESULTS}

\section{Nucleotide sequencing analysis}

The primer set was capable of specifically amplifying a $505 \mathrm{bp}$ product from all isolates included in this study (data not shown). Following cropping of sequences, a final data set spanning nucleotides 111 to 445 of the VHSV N-gene open reading frame was generated. Alignment and analysis of derived nucleotide sequences revealed the occurrence of 38 unique sequences out of 128 examined. In order to avoid the introduction of bias, a second data set was compiled for use in phylogenetic analysis, which included a single representative of each of the 38 unique sequences identified (Table 1). The largest group of identical sequences was comprised of 60 sequences obtained from isolates of wild marine fish recovered largely from within the Baltic and Kattegat Sea areas between 1996 and 1998. This group included sequences derived from VHSV isolates originating from a wide variety of host species, including Atlantic herring Clupea harengus, sprat Sprattus sprattus, cod Gadus morhua, dab Limanda limanda, plaice Pleuronectes platessa, flounder Platichthys flesus and sand goby Pomatoschistus minutus.

\section{Phylogenetic analysis}

The genetic relationships among VHSV sequences are illustrated in the maximum-likelihood derived phylogeny depicted in Fig. 1. The topology of this phylogeny was consistent with that obtained using both distance-based and maximum parsimony methods (not shown). Four major monophyletic groups or genotypes were identified with high bootstrap values. Genotype I was composed of isolates associated with continental rainbow trout farms since 1962 (subgroup $a_{i}$ total number of isolates included designated within this genotype, $\mathrm{n}=21$ ), in addition to a range of more recent isolates from a variety of wild caught marine host species (subgroup $b_{i} \mathrm{n}=66$ ). Marine isolates within this group largely originated in the Baltic Sea or Kattegat areas with the exception of isolate UK-96-43, which was obtained from Atlantic herring caught in the English Channel. Although isolate DK-5p11 is listed from Skagerrak, the delineation of this area is an arbitrary one and the origin of this isolate in ICES (International Council for the Exploration of the Sea) square 43G0 (Mortensen et al. 1999) is very close to the Kattegat area.

Genotype II represented an additional lineage of virus found within the Baltic Sea in herring, sprat and cod $(n=7)$. Genotype III included isolates recovered from a range of wild-caught fish species from the North Sea and East Atlantic in addition to isolates associated with disease outbreaks in farmed turbot. Finally, a fourth genotype included the 2 isolates from North America.

Comparison of inter-genotype variation revealed an average of 14 nucleotide changes between isolates from Genotypes Ia and Ib (4.2\%; Table 2). Average numbers of nucleotide substitutions between other genotypes ranged from 36 to 57 (10.8 to $17.1 \%$; Table 2 ). In terms of amino acid changes, an average of 4 $(3.6 \%)$ occurred between groups $\mathrm{Ia}$ and $\mathrm{Ib}$, and between $12(10.8 \%)$ and 20 (18.0\%) between all other

Table 2. Numbers of differences (within and between group averages) between the 4 major genotypes. Above and below diagonal values refer to nucleotide (total number of sites included $=333$ ) and amino acid values (total number of sites included $=111$ ) respectively. Values were calculated using the 'compute between group means' command as implemented in the MEGA2 software package. This function computes an arithmetic average of the number of differences based on all possible inter-group pairwise comparisons. Values in bold refer to the mean numbers of nucleotide and amino acid differences within each genotype. Values were calculated using the 'compute within group means' command in MEGA2. This function computes an arithmetic average number of substitutions for all valid pairwise comparisons within each genotype. No. of unique sequences refers to the total number of different sequences identified within each genotype. Total no. of isolates in genotype refers to the total number of isolates grouped within each of the genotypes in this study

\begin{tabular}{|c|c|c|c|c|c|}
\hline & Genotype 1a & Genotype $1 \mathrm{~b}$ & Genotype 2 & Genotype 3 & Genotype 4 \\
\hline Genotype 1a & - & 14 & 44 & 40 & 57 \\
\hline Genotype $1 \mathrm{~b}$ & 4 & - & 42 & 37 & 57 \\
\hline Genotype 2 & 14 & 14 & - & 36 & 48 \\
\hline Genotype 3 & 12 & 12 & 14 & - & 49 \\
\hline Genotype 4 & 19 & 20 & 14 & 16 & - \\
\hline Nucleotide & 4 & 2 & 1 & 4 & 5 \\
\hline Amino acid & 1 & 1 & 0 & 1 & 1 \\
\hline No. of unique sequences & 4 & 11 & 2 & 15 & 2 \\
\hline Total no. of isolates in genotype & 21 & 65 & 7 & 30 & 3 \\
\hline
\end{tabular}


groups (Table 2). Mean variabilities within groups were all lower than $5(1.5 \%)$ for nucleotides and 1 $(0.9 \%)$ for amino acids, respectively (Table 2$)$. Pairwise comparison of isolates revealed the maximum level of nucleotide and amino acid variablities within the data set were recorded between Genotype I and Genotype IV isolates (58 substitutions [17.4\%] and 21 substitutions [18.9\%], respectively).

\section{DISCUSSION}

This study supports the distinction of 4 main genotypes of VHSV as previously demonstrated (Snow et al. 1999, Einer-Jensen et al. 2004) and represents the most comprehensive molecular epidemiological study of marine VHSV isolates conducted to date. Its findings fully support classifications made in all previous works based on glycoprotein gene sequences (Benmansour et al. 1997, Stone et al. 1997, Nishizawa et al. 2002, Thiery et al. 2002, Einer-Jensen et al. 2004). This is perhaps not surprising since, in the absence of recombination, the results of molecular epidemiological studies should be independent of the genomic site employed, provided the data are sufficiently robust (Nadin-Davies 2000).

The nomenclature used to define genetic groupings is largely arbitrary, which has lead to differences in the naming of groupings defined by previous studies. This situation could create confusion for fish health professionals who might use such studies to underpin fish disease management decisions. Since this and other studies based on the N-gene (Snow et al. 1999) represent the first to identify the existence of an additional genotype from within the Baltic Sea, the authors suggest the adoption of the nomenclature system reported herein, which is in accordance with that recently adopted by Einer-Jensen et al. (2004).

In agreement with other studies (Benmansour et al. 1997, Snow et al. 1999, Thiery et al. 2002, Einer-Jensen et al. 2004), Genotype I includes isolates associated with rainbow trout aquaculture in continental Europe, in addition to isolates from wild-caught marine fish in the Baltic sea. Strong statistical support was obtained for the existence of this clade, which could be further subdivided into 2 monophyletic groups (Genotypes Ia and Ib, Fig. 1). Genotype Ia included only isolates associated with rainbow trout farming in continental Europe except for a single isolate from farmed turbot (isolate DE-7321, Schlotfeldt et al. 1991, Stone et al. 1997) in Germany. The molecular epidemiological data supports the original suggestion by Schlotfeldt et al. (1991) that the origin of this outbreak was contaminated outlet water from trout rearing units 25 to $35 \mathrm{~km}$ away.
Genotype Ib included isolates originating largely from marine hosts in the Baltic Sea, Skagerrak and Kattegat. Isolate UK-96-43, however, was recovered from wild herring caught in the English Channel. The classification of this isolate within Genotype Ib is at odds with the general correlation between geographic origin and genetic classification. It is, however, possible that this isolation reflects the migratory behaviour of herring stocks, which are known to mix in the Skagerrak and Kattegat.

The inclusion of viruses from freshwater and marine hosts in Genotype I emphasises the close genetic relationship between Genotypes Ia and Ib. Indeed, the average inter-group variability was much lower for Genotypes Ia and Ib than for any other groups. Due to low statistical support values, it was not possible to place the early rainbow trout isolates DK-Hededam (1972) or DK-F1 (1962) within either Genotype I subgroup. Their relative positioning in the phylogram, however, supports the notion that rainbow trout isolates may have originated from a Genotype Ib-like ancestor with the subsequent divergent evolution of Genotypes Ia and Ib. Similar conclusions were drawn in the recent study by Einer-Jensen et al. (2004), who further concluded that Genotypes Ia and Ib diverged from a common ancestor as recently as $50 \mathrm{yr}$ ago. Nucleotide substitution rates of the G-gene in farmed freshwater fish have been suggested to be approximately 2.5 times faster than those in free-living marine fish (Einer-Jensen et al. 2004). One striking feature of the $\mathrm{N}$-gene data set as a whole was the number of identical sequences spanning a number of years and host species, which may support the notion of an increased genetic stability of marine VHSV over that circulating in aquaculture. Given the apparently lower evolutionary rate of marine VHSV, it follows that the common marine ancestor of rainbow trout pathogenic virus is likely to have been most closely related to the early marine Genotype Ib isolates. The origin of the initial introduction of VHSV into rainbow trout is thus most likely to have been within the Baltic Sea area.

Genotype Ia isolates generally originate from disease outbreaks in rainbow trout farms, whereas Genotype $1 \mathrm{~b}$ isolates originate from asymptomatic marine fish species and are of low pathogenicity to rainbow trout following water-borne challenge (Dixon et al. 1997, Skall et al. 2004). Thus, an adaptation to virulence in rainbow trout appears to have occurred along with the emergence of Genotype Ia isolates. RNA viruses are known to be highly adaptable and exhibit high mutation rates (for review see Holland \& Domingo 1998). Selection pressures imposed by intensive aquaculture are thought to be a driving force behind the high rates of evolution observed in both Genotype Ia VHSV (Einer-Jensen et al. 2004) and 
infectious haematopoietic necrosis virus infecting cultured salmonids in North America (Troyer \& Kurath 2003, Kurath et al. 2003). Such anthropogenic effects, including the use of unpasteurised marine feed products in the aquaculture industry, may have contributed to the original emergence of rainbow trout pathogenic VHSV from a marine ancestor.

The second genetic group of isolates supported by this study has been extended to include 7 isolates originating from the Baltic Sea. The identification of a unique genotype within the Baltic Sea could suggest the occurrence of a secondary introduction event into this area at some stage. Alternatively, divergent evolution following occupation of different ecological niches may be, at least in part, responsible for the maintenance of such diversity within the Baltic Sea. Indeed, it has been suggested that these isolates might originate from a discrete fish population endemic to a deep water Eastern Gotland Basin within the Baltic Sea (Einer-Jensen et al. 2004). What is clear is that Genotype II appears to represent an additional marine lineage, with no clear link to rainbow trout aquaculture, which only serves to strengthen the argument that the origin of freshwater VHSV was most probably in the marine environment. This, coupled to the previous evidence presented, indicates that VHSV was probably not introduced into the marine environment as a result of rainbow trout aquaculture activity in the watersheds that supply the Baltic Sea. This, however, is not to say that subsequent re-introduction from such sources has not occurred.

Genotype III has been extended to include over 30 isolates from the marine environment around the British Isles and includes 2 isolates recovered from outbreaks of VHS in Irish and Scottish turbot farms. Such evidence suggests that the origin of the virus in these outbreaks was the local marine environment and as such, highlights a continued risk to the developing turbot aquaculture industry. Indeed, the demonstration that viruses from this genotype are virulent for turbot provides direct evidence of such risk (Snow \& Smail 1999, King et al. 2001b).

Finally, Genotype IV included VHSV isolates from North America, where VHSV has been repeatedly isolated from marine hosts since the late 1980s (Brunson et al. 1989, Hopper 1989, Meyers et al. 1992, 1994, Traxler \& Kieser 1994, Meyers \& Winton 1995, Meyers et al. 1999, Dopazo et al. 2002, Hedrick et al. 2003). Indeed, it was this evidence coupled to the fact that VHS disease has not emerged as a problem in North American aquaculture that proved to be a significant factor in first implicating the marine origin of VHSV in Europe. This genotype has been most extensively studied by Nishizawa et al. (2002), who extended its range to include a range of VHSV isolates from Japan- ese flounder in addition to a number of wild fish isolates from the Pacific Northwest. The occurrence of a distinct VHSV genotype (Genotype IV) both in Japan and in the Pacific Northwest, where the disease has never been recorded in rainbow trout, further suggests that a marine reservoir of virus was in existence long before the development of commercial aquaculture in Europe. Indeed, estimates by Einer-Jensen et al. (2004) suggest that Genotypes I and IV diverged around $500 \mathrm{yr}$ ago. Such findings lend further credence to the hypothesis that VHSV, which is responsible for considerable losses to European rainbow trout aquaculture, originated in the marine environment (for review see Dixon 1999).

Considerable evidence thus exists to indicate that rainbow trout pathogenic VHSV emerged from a Genotype I-type marine ancestor. The evolutionary scenario we describe may be explained by the occurrence of a single introduction or adaptation event followed by expansion of Genotype Ia within trout aquaculture. The existence of such a monophyletic group (Genotype Ia) was supported by the recent study of Einer-Jensen et al. (2004). These workers did, however, identify rainbow trout pathogenic isolates from Sweden within Genotype $\mathrm{Ib}$, which were probably introduced via direct contact with marine hosts (EinerJensen et al. 2004). Recent isolates from marine cultured rainbow trout, which were associated with the use of marine feed products in Finland, were also classified in a separate subgroup (Genotype 1d). These findings suggest that rainbow trout pathogenic isolates may have emerged from a Genotype I ancestral source on more than one occasion. The apparent increased risk of re-emergence of Genotype I rainbow trout pathogenic isolates might be related to greater potential contact of rainbow trout with VHSV of this genotype. Indeed, such events might be related to an increased prevalance of marine Genotype I isolates coupled with a high level of rainbow trout aquaculture activity within the Baltic Sea. Alternatively, marine Genotype I isolates may have an intrinsic genetic predisposition towards evolution into a rainbow trout virulent phenotype as compared to other genotypes. Indeed, none of the other genotypes has been associated with disease in rainbow trout aquaculture, despite apparent opportunities for their introduction.

This study has extended our knowledge of the genetic population structure of marine VHSV. Its findings are of significance to the future management of VHSV in Europe, which is currently based on the maintenance of approved zones, where the disease or agent have not been recorded. The acknowledgement of a marine distribution of VHSV, coupled to a lack of distinction between this and rainbow trout pathogenic forms is making the maintenance of such zones 
increasingly difficult to defend. The method reported herein represents a relatively simple technique with the capacity to both detect and characterise all known variants of VHSV reported to date. Such a tool, coupled to an understanding of the pathogenicity and host-specificity characteristics of marine VHSV is fundamental to future VHS disease management.

\section{LITERATURE CITED}

Akaike H (1974) A new look at statistical model identification. IEEE (Inst Electr Electron Eng) Trans Automatic Control 19:716-723

Benmansour A, Basurco B, Monnier AF, Vende P, Winton JR, de Kinkelin P (1997) Sequence variation of the glycoprotein gene identifies three distinct lineages within field isolates of viral haemorrhagic septicaemia virus, a fish rhabdovirus. J Gen Virol 78:2837-2846

Brudeseth BE, Evensen $\varnothing$ (2002) Occurrence of viral haemorrhagic septicaemia virus (VHSV) in wild marine fish species in the coastal regions of Norway. Dis Aquat Org 52: 21-28

Brunson R, True K, Yancey J (1989) VHS virus isolated at Makah National Fish Hatchery. Am Fish Soc Newsl 17:3

Dixon PF (1999) VHSV came from the marine environment: Clues from the literature, or just red herrings? Bull Eur Assoc Fish Pathol 19:60-65

Dixon PF, Feist S, Kehoe E, Parry L, Stone DM, Way K (1997) Isolation of viral haemorrhagic septicaemia virus from Atlantic herring Clupea harengus from the English Channel. Dis Aquat Org 30:81-89

Dopazo CP, Bandin I, Lopez-Vasquez C, Lamas J, Noya M, Barja JL (2002) Isolation of viral hemorrhagic septicemia virus from Greenland halibut Reinhardtius hippoglossoides caught at the Flemish Cap. Dis Aquat Org 50: 171-179

Einer-Jensen K, Ahrens P, Forsberg R, Lorenzen N (2004) Evolution of the fish rhabdovirus viral haemorrhagic septicaemia virus. J Gen Virol 85:1167-1179

Felsenstein J (1985) Confidence limits on phylogenies: an approach using the bootstrap. Evolution 39:783-791

Fijan N, Sulimanovic D, Bearzotti M, Muzinic D, Zwillenberg LO, Chilmonczyk S, Vautherot JF, de Kinkelin P (1983) Some properties of the epithelioma papulosum cyprini (EPC) cell line from carp (Cyprinus carpio). Ann Inst Pasteur/Virol 134:207-220

Hedrick RP, Batts WN, Yun S, Traxler GS, Kaufman J, Winton JR (2003) Host and geographic range extensions of viral hemorrhagic septicaemia virus. Dis Aquat Org 55: 211-220

Holland J, Domingo E (1998) Origin and evolution of viruses. Virus Genes 16 (1):13-21

Hopper K (1989) The isolation of VHSV from chinook salmon at Gleenwood Springs, Orcas Island, Washington. Am Fish Soc Newsl 17:1

Jensen NJ, Bloch B, Larsen JL (1979) The ulcus-syndrome in cod (Gadus morhua) III. A preliminary virological report. Nord Vet-Med 31:436-442

King JA, Snow M, Smail DA, Raynard RS (2001a) Distribution of viral haemorrhagic septicaemia virus in wild fish species of the North Sea, north east Atlantic Ocean and Irish Sea. Dis Aquat Org 47(2):81-6

King JA, Snow M, Skall HF, Raynard RS (2001b) Experimental susceptibility of Atlantic salmon Salmo salar and turbot Scophthalmus maximus to European freshwater and marine isolates of viral haemorrhagic septicaemia virus. Dis Aquat Org 47:25-31

Kumar S, Tamura K, Jakobsen IB, Nei M (2001) MEGA2: molecular evolutionary genetics analysis software. Bioinformatics 17(12):1244-1245

Kurath G, Garver KA, Troyer RM, Emmenegger EJ, EinerJensen K, Anderson ED (2003) Phylogeography of infectious hematopoietic necrosis virus in North America. J Gen Virol 84:803-814

Le Berre M, de Kinkelin P, Metzger A (1977) Identification serologique des rhabdovirus des salmonides. Bull Off Int Epizoot 87:391-393

Lorenzen N, Olesen NJ, Jørgensen PEV (1993) Antibody response to VHS virus proteins in rainbow trout. Fish Shellfish Immunol 3:461-473

Meyers TR, Sullivan J, Emmenegger E, Follet J, Short S, Batts WN, Winton JR (1992) Identification of viral hemorrhagic septicemia virus isolated from Pacific cod Gadus macrocephalus in Prince William Sound, Alaska, USA. Dis Aquat Org 12:167-175

Meyers TR, Short S, Lipson K, Batts WN, Winton JR, Wilcock J, Brown E (1994) Association of viral hemorrhagic septicemia virus with epizootic haemorrhagaes of the skin in Pacific herring Clupea harengus pallasi from Prince William Sound and Kodiak Island, Alaska, USA. Dis Aquat Org 19:27-37

Meyers TH, Winton JR (1995) Viral hemorrhagic septicemia of non-salmonids. Annu Rev Fish Dis 4:359-373

Meyers TH, Short S, Lipson K (1999) Isolation of the North American strain of viral hemorrhagic septicemia virus (VHSV) associated with epizootic mortality in two new host species of Alaskan marine fish. Dis Aquat Org 38: 81-86

Mortensen HF, Heuer OE, Lorenzen N, Otte L, Olesen NJ (1999) Isolation of viral haemorrhagic septicaemia virus (VHSV) from wild marine fish species in the Baltic sea, Kattegat, Skagerrak and the North Sea. Virus Res 63: 95-106

Nadin-Davis SA (2000) Rabies and rabies-related viruses. In: Thompson RCA (ed) Molecular epidemiology of infectious disease. Arnold, London, p 245-257

Nishizawa $T$, Iida $H$, Takano $R$, Isshiki $T$, Nakajima $K$, Muroga K (2002) Genetic relatedness among Japanese, American and European isolates of viral hemorrhagic septicemia virus (VHSV) based on partial G and P genes. Dis Aquat Org 48(2):143-8

Posada D, Crandall KA (1998) MODELTEST: testing the model of DNA substitution. Bioinformatics 14:817-818

Ross K, McCarthy U, Huntly PJ, Wood P, Stuart D, Rough EI, Smail DA, Bruno DW (1994) An outbreak of viral haemorrhagic septicaemia (VHS) in turbot (Scophthalmus maximus) in Scotland. Bull Eur Assoc Fish Pathol $14(6) 213$

Schlotfeldt HJ, Ahne W, Jørgensen PEV, Glende W (1991) Occurrence of viral haemmorhagic septicaemia in turbot (Scophthalmus maximus) - a natural outbreak. Bull Eur Assoc Fish Pathol 11(3):105-107

Skall HF, Slierendrecht WJ, King JA, Olesen NJ (2004) Experimental infection of rainbow trout Oncorhynchus mykiss with viral haemorrhagic septicaemia virus isolates from European marine and farmed fishes. Dis Aquat Org 58: 99-110

Smail DA (1995) Isolation and identification of viral haemorrhagic septicaemia (VHS) virus from north sea cod (Gadus morhua L.). ICES Maricult Comm Rep CM 1995/f:15

Smail DA (2000) Isolation and identification of Viral Haemorrhagic Septicaemia (VHS) viruses from cod Gadus morhua 
with the ulcus syndrome and from haddock Melanogrammus aeglefinus having skin haemorrhages in the North Sea. Dis Aquat Org 41(3):231-5

Snow M, Smail DA (1999) Experimental susceptibility of turbot Scophthalmus maximus to viral haemorrhagic septicaemia virus isoloted from cultivated turbot. Dis Aquat Org 38:163-168

Snow M, Cunningham CO, Melvin WT, Kurath G (1999) Analysis of the nucleoprotein identifies distinct lineages of viral haemorrhagic septicaemia virus within the European marine environment. Virus Res 63:35-44

Snow M, Barja J, Colquuhoun D, Cunningham C and 11 others (2004) Development of a European resource on the origins of pathogens of aquaculture: The EUROPA Project. Bull Eur Assoc Fish Pathol 24:54-57

Stone DM, Way K, Dixon PF (1997) Nucleotide sequence of the glycoprotein gene of viral haemorrhagic septicaemia (VHS) viruses from different geographical areas: a link between VHS in farmed fish species and viruses isolated from North Sea cod (Gadus morhua L.). J Gen Virol 78:1319-1326

Swofford DL (1993) PAUP: Phylogenetic analysis using parsimony, Version 3.1. Illinois natural history survey, Champaign, IL

Editorial responsibility: Jo-Ann Leong,

Kaneohe, Hawaii, USA
Thiery R, de Boisseson C, Jeffroy J, Castric J, de Kinkelin $\mathrm{P}_{\mathrm{r}}$ Benmansour A (2002) Phylogenetic analysis of viral haemorrhagic septicaemia virus (VHSV) isolates from France (1971-1999). Dis Aquat Org 52:29-37

Traxler GS, Kieser D (1994) Isolation of the North American strain of viral hemorrhagic septicemia virus (VHSV) from herring (Clupea harengus pallasi) in British Columbia. Am Fish Soc Newsl 22:8

Troyer RM, Kurath G (2003) Molecular epidemiology of infectious hematopoietic necrosis virus reveals complex virus traffic and evolution within southern Idaho aquaculture. Dis Aquat Org 55:175-185

van Regenmortel MHV, Fauquet CM, Bishop DHL, Carstens EBO (2000) Virus taxonomy: the classification and nomenclature of viruses. The Seventh International Report of the International Committee on Taxonomy of Viruses. Academic Press, San Diego, CA

Vestergård Jørgensen PE (1974) A study of viral diseases in Danish rainbow trout, their diagnosis and control. PhD thesis, Den Kongelige Veterinær- og Landbohøjskole, Copenhagen

Wolf K, Quimby MC (1966) Lymphocystis virus: isolation and propagation in centrarchid fish cell lines. Science 151: $1004-1005$

Submitted: October 8, 2003; Accepted: June 21, 2004 Proofs received from author(s): September 14, 2004 